U.S. Department of Energy

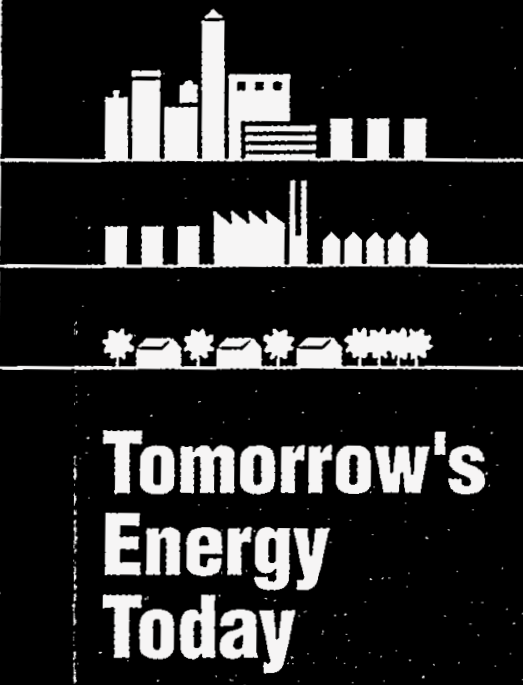

for Cities and Cotinties

$\frac{27}{2-17}-95$ y $<11$

DOE/CH $10093-273$

\title{
Blazing the Energy Trail: The Municipal Energy Management Program
}

\section{The Urban Consortium Energy Task Force pioneers energy and environmental solutions for U.S. cities and counties. When local officials participate in the task force, they open the door to many resources for their communities.}

MISTRIBUTION OF THIS DOCUMENT IS UNLIMITED

The United States is entering a period of renewed interest in energy management. Improvements in municipal energy management allow communities to free up energy operating funds to meet other needs. These improvements can even keep energy dollars in the community through the purchase of services and products used to save energy.

With this idea in mind, the U.S. Department of Energy Municipal Energy Management Program has funded more than 250 projects that and dollar savings.

Buildings, including lighting, represent an area of opportunity for achieving substantial energy

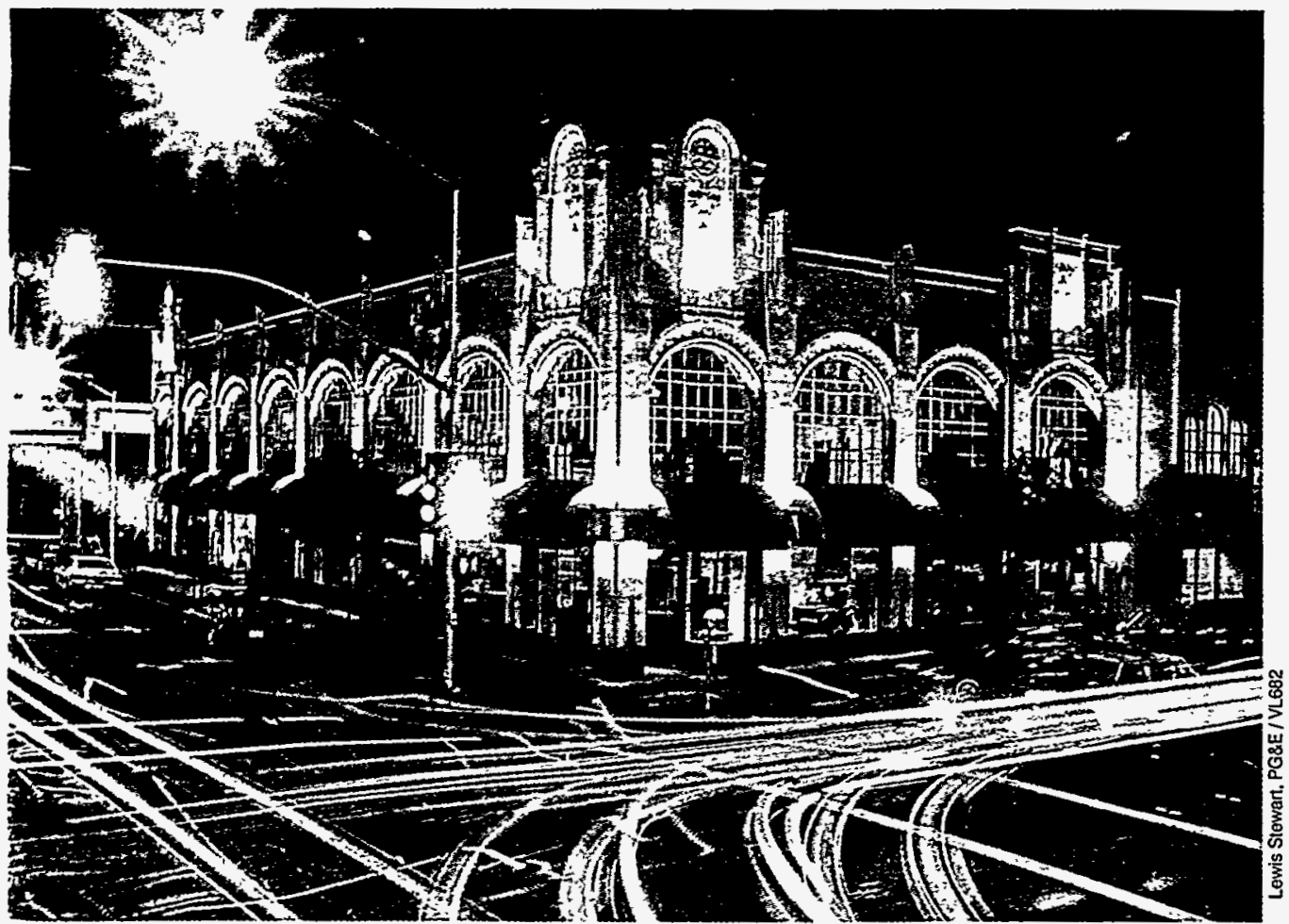

demonstrate innovative energy technologies and management tools in cities and counties through the Urban Consortium Energy Task Force (UCETF). UCETF helps the U.S. Department of Energy foster municipal energy management through networks with cities and urbanized counties and through links with three national associations of local governments - the National League of Cities, the National Association of Counties, and the International City/County Management Association.

UCETF provides funding for projects that demonstrate innovative and realistic technologies, strategies, and methods that help urban America become more energy efficient and environmentally responsible. The task force provides technical support to local jurisdictions selected for projects (for information on the selection process, see p. 5).

UCETF also shares information about successful energy management projects with cities and counties throughout the country via technical reports and project papers. The following descriptions capsulize a sample of UCETF's demonstration projects around the country.

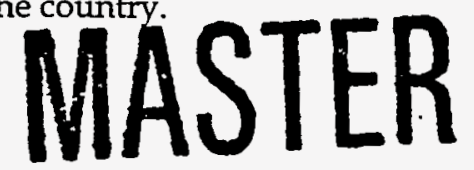




\section{DISCLAIMER}

This report was prepared as an account of work sponsored by an agency of the United States Government. Neither the United States Government nor any agency thereof, nor any of their employees, make any warranty, express or implied, or assumes any legal liability or responsibility for the accuracy, completeness, or usefulness of any information, apparatus, product, or process disclosed, or represents that its use would not infringe privately owned rights. Reference herein to any specific commercial product, process, or service by trade name, trademark, manufacturer, or otherwise does not necessarily constitute or imply its endorsement, recommendation, or favoring by the United States Government or any agency thereof. The views and opinions of authors expressed herein do not necessarily state or reflect those of the United States Government or any agency thereof. 


\section{DISCLAIMER}

Portions of this document may be illegible in electronic image products. Images are produced from the best available original document. 


\begin{tabular}{l}
\hline "Communities are \\
\hline sitting on a gold mine \\
\hline of potential savings. \\
\hline One of the primary \\
\hline ways to save is to \\
\hline reduce the municipal \\
\hline government energy bill." \\
\hline $\begin{array}{l}\text { - Mike Lindberg } \\
\text { Clairperson } \\
\text { uCETF }\end{array}$
\end{tabular}

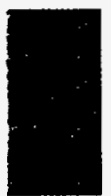

At-risk youtl constructed the Green Builder Model Home for Austin's Habitat for Humanity. This photo shows at-risk youth working on another Green Builder house.

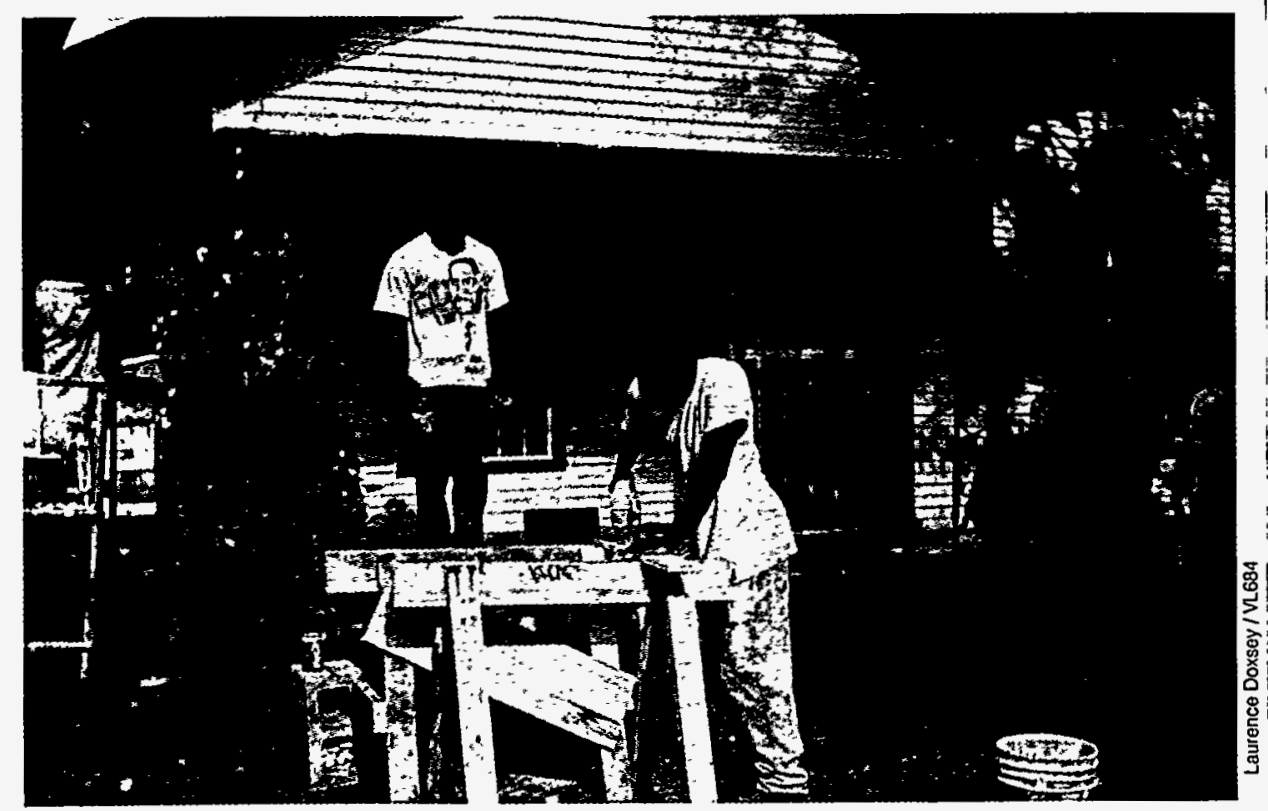

\section{Building on a Recycled Foundation in Austin, Texas}

From the $40 \%$ fly ash concrete slab to the recycled-content roof, the Green Builder Model Home in Austin, Texas, is an example of what could be the future of home building in America. Each nuance of the design, which the city calls "green building," indicates the environmental friendliness of this house. Among the features are:

- A brick facade that is $20 \%$ coal bottom ash (residue left from burning coal)

- Doors made of reconstituted wood

- $100 \%$ recycled-content carpet in the bedrooms

- Natural linoleum (made from cork and other natural materials) instead of vinyl linoleum on the kitchen and bathroom floors and countertops

- Recycling centers built into the pantry

- Cotton for attic insulation

- Exposed concrete in the living area for passive solar heat storage

- Several south-facing windows

- A large porch on the western side to protect the home from the intense summer sun

- High-efficiency fluorescent lighting throughout.
The model home is part of the Green Builder Program, which is coordinated through Austin's Environmental and Conservation Services Department. The Green Builder Program seeks to shift home building practices to approaches that not only use energy, water, and other natural resources more efficiently, but also preserve the environment, strengthen the local economy, and enhance the quality of life for Austin citizens. This program also demonstrates sustainability concepts for the building community.

The 1100-square-foot (102-squaremeter) home, which is located in an existing subdivision, took 6 months to build, "partly because of the learning curve of dealing with new materials," said Laurence Doxsey, Coordinator of Austin's Green Builder Program, "and partly because of untrained workers." Those workers consisted of at-risk youth, all on parole, from the American Institute for Learning, one of the project partners. Several private firms also donated some materials.

UCETF supplied $\$ 25,000$ of the money needed for this endeavor. Austin's Habitat for Humanity picked up the rest, which came to $\$ 42,500$. That's about $\$ 5,000$ more than Habitat for Humanity would normally put into a house. Doxsey says the increase can be attributed to a budget overrun on the house's foundation. Otherwise, the home would have been less costly to build than a comparable home using traditional materials (e.g., lumber). In addition, projections indicate that the home will require $30 \%$ less electrical energy than a traditional home of the same size at the same location.

Part of this project will include an analysis of the economic development potential of using the regional waste stream as a source for building materials. Builders will be able to 
"The most important

thing about UCETF

staff from different

areas to get together

and share information."

- John Deakin

Director

Bureau of Energy Conservation

City of San Francisco is that it allows energy

the potential for global warming by reducing carbon dioxide emissions. As a low-lying coastal community, the county is particularly vulnerable to some potential effects of global warming-flooding, saltwater intrusion, population shifts, water shortages, and agricultural damage. And as the only subtropical city in the project, Metro-Dade is a potential model for similar metropolitan areas around the world. UCETF initially awarded $\$ 50,000$ for the project in 1992 , then awarded another $\$ 50,000$ in 1993 for continuation of the project.

After 2 years of gathering data, Metro-Dade has come up with a 35-point plan to reduce carbon dioxide emissions to 1988 levels by 2005 . Much of that plan addresses transportation, alone responsible for $45 \%$ of Metro-Dade's carbon dioxide emissions in 1988. Currently, more than $97 \%$ of the county's population travels via single-occupancy vehicles.

Because vehicle emissions are a major contributor to carbon dioxide accumulation, the Metro-Dade Board of Commissioners sent a resolution to

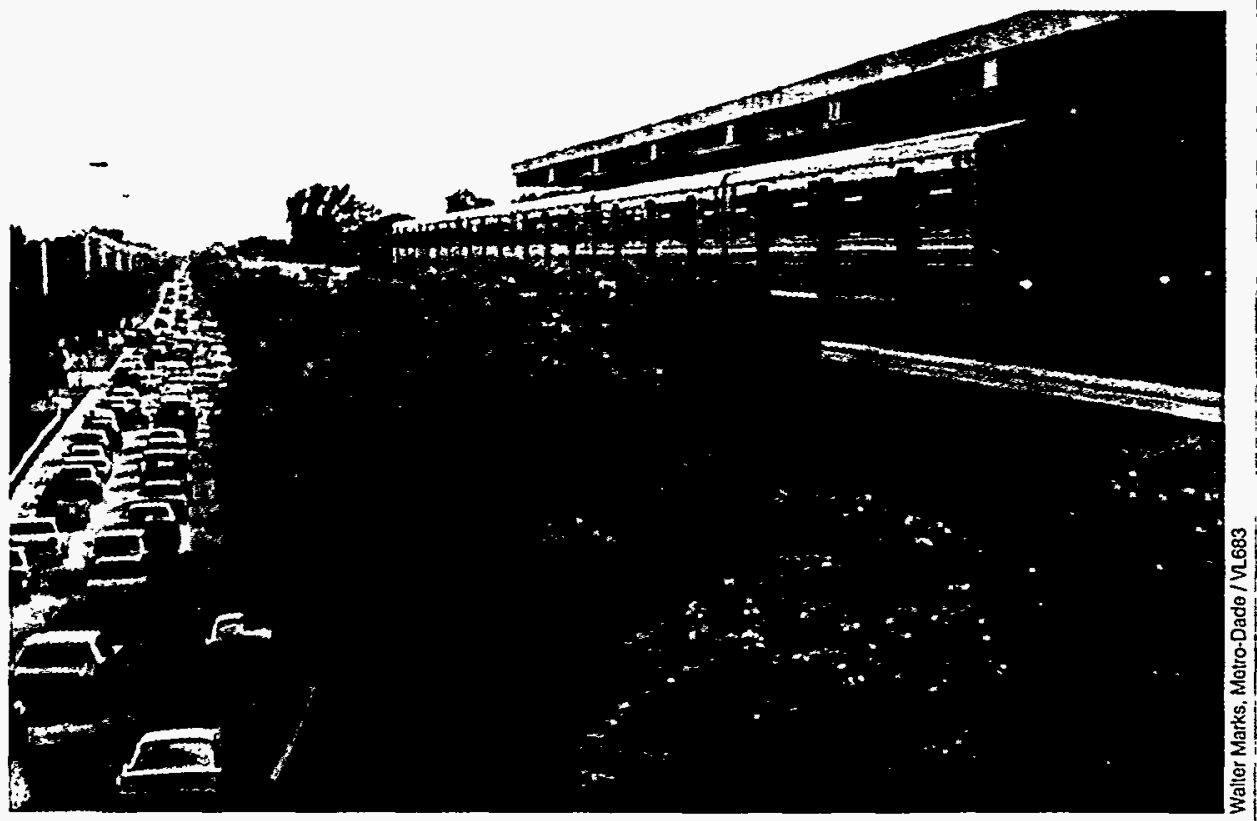

Rail systems help Metro-Dade County reduce carbon dioxide emissions from transportation, responsible for $45 \%$ of Metro-Dade's carbon dioxide emissions in 1988. the President, and to the county's Congressional delegation, that advocates increasing Corporate Average Fuel Economy (CAFE) standards for cars from 27.5 miles per gallon (44 kilometers per gallon) to 45 miles per gallon (72 kilometers per gallon). CAFE standards are federal regulations that specify a minimum average fuel economy to be met by car and light-truck manufacturers.

The county also plans to change transportation patterns by encouraging transit use, group travel, and telecommuting through a combination of employer incentives and county programs. The carbon dioxide reduction plan even calls for professional office buildings to add shower facilities to make cycling more attractive to commuters.

The carbon dioxide reduction plan has precipitated several more changes for Metro-Dade. The county is revising its landscape ordinance to require strategic tree planting, street trees, and parking lot trees, which can provide shading and cooling to help reduce energy demands. Metro-Dade is also expanding the solid-waste recycling program and is planning to capture and use landfill gases such as methane.

\section{Conclusion}

UCETF provides a unique, creative forum to define and ameliorate common urban problems and to validate practical ways to enhance local government services. The Task Force's accomplishments have led the way in creating strategic energy programs that save scarce resources and create revenue for cities and counties. By working with UCETF, local governments gain tangible benefits such as peer networking and participating in priority energy research and development. 


\section{Making Local Energy Issues its Business}

The Urban Consortium Energy Task Force (UCETF) has completed more than 250 demonstration and technology transfer projects in urban jurisdictions. These projects explore, test, and validate new energy management approaches, technologies, and policies.

The task force shares information about its projects with cities and counties throughout the country via technical reports, project papers, video teleconferencing, videos, conferences, presentations to city and county governments, and news articles.

And, through UCETF's peer-to-peer assistance teams, officials from cities and counties can sit down face to face and discuss the challenges they're experiencing. "This peer-to-peer exchange is one of the most important components of this task force," says John Deakin, Director of San Francisco's Bureau of Energy Conservation. "You can find somebody from a city who's facing the same kind of problems you are."

The premise is simple: Why reinvent the whee/? UCETF arranges discussion among project participants so that all can benefit from another's experiences. Each year, cities and counties that receive UCETF project funds get together for a kickoff meeting. At this meeting, the individual projects are subdivided into "programmatic units" of similar projects. Then, during the following spring and fall, the programmatic units meet again "to hear what everyone else is doing and offer help," Deakin adds.

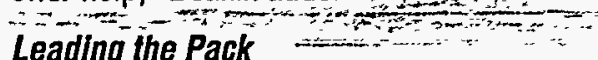
At the helm of UCETF is Michael Lindberg, also Commissioner of Public Utilities for the city of Portland, Oregon. Lindberg says the Task Force's activities actually demonstrate to cities and counties ways to save energy and dollars. "Communities are sitting on a gold mine of potential savings. One of the primary ways to save is to reduce the municipal government energy bill," he adds.
Lindberg believês UCEIEprovides a needed forum that allows energy officials from America's cities and coünties to exchange information and ideas: "And" whatever level of government you're in, you'll find people like yourself "he says.

The group directly responsible for UCETF activities comprises 20 management and technical professionals from urban cities and counties. These experienced energy professionals are committed to developing local strategies responsive to the national energy situation Staff members from Public Technology; Inc , handle day to-day operations and provide support services to the UCEIF chairperson and Task Force members:

\section{Applying for UCETF Fünds}

Each year, UCETF requests proposals from major urban jurisdictions. After a rigorous review process, UCETFfunds. those projects that best define and demonstrate innovative and realistic technologies, strategies, and methods that can facilitate urban America's attempts to become more energy efficientand environmentally responsible.

Cities and counties with populations of more than 250,000 are eligible for the applied research and demoñstration projects; those with populations of more than 100,000 are eligible;for technology transfer projects. Smaller municipalities may join together to submit proposals: Local governments can receive up to $\$ 75,000$ for UCETF applied research and development projects; which are designed to improve local government services and economic climate they can receive up to $\$ 25,000$ for technólogy transfer projects, which are designed to transfer information from previous projects to ôther cities and counties.

For each year's program, projectsare organized around as specific theme. For example, the 1994 demonstration projects are focused on sustainable commu nities (communities that preserve a livable environmentfor füturégenerations) and economicovelopment

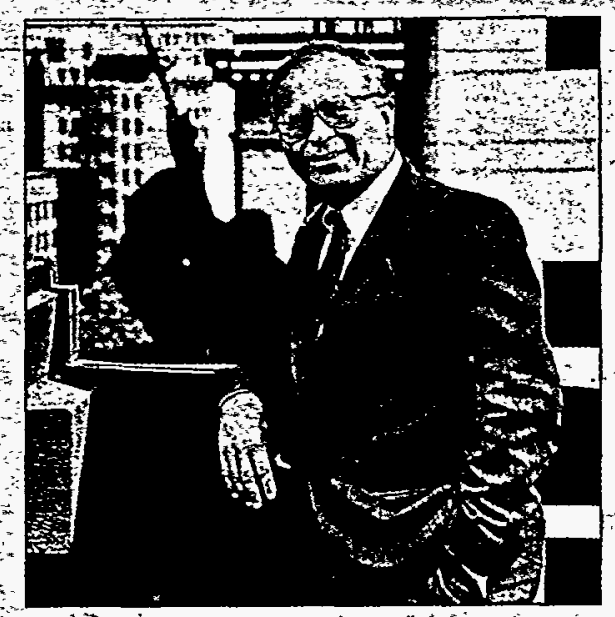

Mike Lindberg, Chairperson, UCETF

Selected projects are funded for 1 year. If a project requires more than 1 year to complete, it should be phased to allow for tangible deliverables by the end of the first year. Second-year funding is not guaranteed, however, and depends on submission of a new proposal, satisfactory completion of the first phase, and the availability of funds.

For all proposals, partnerships with other public-or private-sector entities are requited and are intended to challenge participating cities and counties to form joint ventures to enhance project success and implementation. These partnerships encourage mutually developed solutions and creation of an infrastructure to effectively support projects and ensure their continuation beyond the funding period. Partners can contribute resources other than money. For more information about UCETF's request for proposals, contact Public Technólogy, Inc., at (202) 626-2400, or Mike Lindberg, UCETF Chairperson, at (503) 823-4890. 


\section{For More Information}

Mike Lindberg, Chairperson Urban Consortium Energy Task Force Portland, OR 97204 (503) $823-4145$

Public Technology, Inc. 1301 Pennsylvania Avenue, NW Washington, DC 20004-1793 (202) $626-2400$

\section{Linda Graves}

Municipal Energy Management Program

U.S. Department of Energy, EE-522

1000 Independence Avenue, SW

Washington, DC 20585

(202) 586-1851

John F. Deakin

Bureau of Energy Conservation

1155 Market Street, 4th Floor

San Francisco, CA 94103

(415) 554-3180

Laurence Doxsey

Green Builder Program

Environmental Conservation and Services Department

206 East 9 th Street, Suite 17.102

Austin, TX 78701

(512) 499-3504

\section{DOE Regional Support Offices}

The DOE Office of Energy Efficiency and Renewable Energy reaches out to thestates and private industry through a network of regional support offices. Contactyour.DOEregional: support office for information on energy efficiency and renewable energy technologies:

Atlanta DOE Support Office

730 Peachtree Street NE, Suite 876

Atlanta, GA 30308

(404) 347-2837

(AL, FL, GA, KY, MS, NC, PR, SC, TN; Territory: VI)

Boston DOE Support Office

One Congress Street, 11th Floor

Boston, MA 02114

(617) 565-9700

(CT, MA, ME, NH, RI, VT)

\section{Chicago DOE Support Office}

9800 South Cass Avenue

Argonne, IL 60439

(708) 252-2220

(IL, IN, MI, MN, OH, WI)

Dallas DOE Support Office

1420 West Mockingbird Lane, Suite 400

Dallas, TX 75247

(214) 767-7245

(AR, LA, NM, OK, TX)

Denver DOE Support Office

2801 Youngfield Street, Suite 380

Golden, CO 80401

(303) 231-5750

(CO, MT, ND, SD, UT, WY)

Susan Berryman-Rodriguez

Urban $\mathrm{CO}_{2}$ Reduction Program

Department of Environimental Resources

33 SW 2nd Avenue

Miami, FL 33130

(305) 372-6758

Rita Norton

Conservation and Resource Management.

Program

777 North 1st Street, Suite 450

San Jose, CA 95112

(408) 277-5533

EREC

P.O. Box 3048

Merrifield, VA 22116

(800) 363-3732

The Energy Efficiency and Renewable Energy

Clearinghouse (EREC) is a service funded by

the U.S. Department of Energy to provide information on renewable energy and energy efficiency technologies.

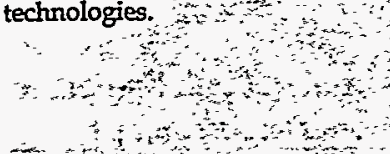

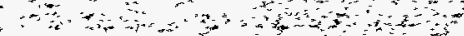
$+x_{2}+4$

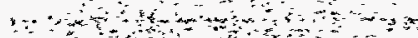
and

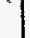

